\title{
KONSEP EKONOMI POLITIK DALAM PERSPEKTIF IBNU KHALDUN
}

\author{
Moh. Qudsi Fauzi \\ Departemen Ekonomi Syariah-Fakultas Ekonomi dan Bisnis-Universitas Airlangga \\ Email: alifalinsany@gmail.com \\ Muhammad Alif Al Insany \\ Departemen Ekonomi Syariah-Fakultas Ekonomi dan Bisnis-Universitas Airlangga \\ Email: qudsi01@gmail.com
}

\begin{abstract}
:
This research aimed to find out the political economy concepts that existed in Ibn Khaldun's thoughts through his magnum opus of Muqaddimah, which was a part of Al-Ibar book. This research used the literature study method by studying the literature related to the political economy. Literature data interpretation has been made by using historical analysis technique, which consists of periodization stages based on the life of Ibn Khaldun, and by historical descriptive analysis technique which is related to the political economy thoughts of Ibn Khaldun. This research showed that economics and politics have a relation since, in the past, especially in a life span of Ibn Khaldun and his thoughts about political economy, such as production, work division, wage theory and the like. These thoughts were firstly presented by Ibn Khaldun before the classical period economists did. Therefore, these thoughts are essential to study further to provide suggestions for economic studies, especially Islamic economic studies.
\end{abstract}

Keywords: Political Economy, Ibn Khaldun, Economic Politics.

\section{PENDAHULUAN}

Ada beberapa alasan penyebab kesenjangan yang disebutkan di Oxfam Briefing Paper, salah satunya ialah capitalism atau kapitalis (Hardoon, 2017:4). Dalam sejarah ekonomi, kapitalis menyebabkan krisis pada negara yang mengusung paham tersebut, seperti Amerika. Menurut Endy Suhadi Hamid (2009:3), Krisis Finansial yang terjadi di Amerika tidak bisa dilepaskan dari the nature of capitalism yang sudah mengakar pada sistem ekonomi mainstream yang di usung sebagian besar negara di dunia. Dalam sistem ekonomi kapitalisme meyakini bahwa pasar memiliki self-correcting yang menjamin tercapainya equilibrium setiap gejolak terjadi. Market fundamentalisme menjadi dominan dalam ideologi ini kemudian menyebabkan maraknya transaksi yang berbasis spekulasi tanpa pijakan yang riil hanya menambah menggelembungnya ekonomi (bubble economy), dan menunggu waktu untuk gelembung meledak sehingga menimbulkan krisis serta dampak dan efek negatif bagi perekonomian.

Crony capitalism juga disebutkan Oxfam Briefing Paper (Hardoon, 2017:4) menjadi salah satu faktor kesenjangan ekonomi terjadi, dimana pelaku ekonomi memiliki hubungan dengan political leaders atau kalangan pemerintahan. Shang-Jin Wei (2001:21) menyebutkan crony capitalism dalam kata lain corruption involving government officials mengandung arti korupsi yang melibatkan pemerintah. Hal ini menjadikan kehidupan ekonomi tidak begitu jauh dari kehidupan 
politik. Keterkaitan antara ekonomi dan politik disebut ekonomi-politik.

Landasan-landasan ekonomi

politik yang dikemukakan oleh Adam Smith maupun David Ricardo sudah rumuskan jauh beberapa abad ke belakang oleh Ibnu Khaldun. Dalam buku yang berjudul History of Economic Analysis, Schumpter memiliki argumentasi bahwa economic analysis begins only with the Greeks. Schumpter tidak mencari tahu akan Ibnu Khaldun hingga akhir dalam perjalanan hidupnya, mendeklarasikan bahwa lbnu Khaldun was for more original than Adam Smith yang berarti landasanlandasan ekonomi politik yang dirumuskan oleh Ibnu Khaldun lebih dulu dari Adam Smith (Al-Hamdi, 2006:2).

Melalui buku Muqaddimah, Ibnu Khaldun memberikan landasanlandasannya terhadap ekonomi politik, salah satunya tentang persoalan harga. Ibnu Khaldun berpendapat bahwa harga adalah hasil dari hukum permintaan dan penawaran. Pengecualian dari hukum ini ialah harga emas dan perak yang merupakan standar dari moneter. Harga semua barang bergantung pada pasar. Bila penawaran barang sedikit atau langka dan banyak permintaan, maka harga didapat akan tinggi. Berbeda jika barang memiliki penawaran yang melimpah, maka harganya rendah (Iqbal, 2012:9).

Berangkat dari seorang cendekiawan muslim yang mendahului pemikiran dari Adam Smith yaitu Ibnu Khaldun. Cendekiawan yang lahir pada
The Golden Age, sebutan masa peradaban umat islam mengalami puncak kejayaan. Hal ini menjadikan landasan-landasan Ibnu Khaldun mengenai Ekonomi Politik menjadi menarik untuk diteliti, terlebih lagi dengan karyanya yang berjudul Muqaddimah. Dengan hal ini maka peneliti tertarik melakukan penelitian dengan mengangkat judul konsep ekonomi politik dalam pemikiran Ibnu Khaldun.

II. LANDASAN TEORI

\section{Definisi Ekonomi Politik dan Keterkaitan Ekonomi dengan Politik}

Menurut Staniland dalam Deliarnov (2006:8), ekonomi politik memiliki makna sebuah studi tentang teori sosial dan keterbelakangan. Namun ada juga pandangan lain jika ekonomi politik tidak terbatas pada studi tentang teori sosial dan keterbelakangan. Hal ini dikemukakan oleh Caporaso \& Levine dalam Deliarnov (2006:8), menurutnya ekonomi politik memiliki maksud untuk memberikan saran mengenai pengelolaan pemasalahan dalam ekonomi kepada para penyelenggara negara.

Dalam pemaknaan politik sebagai otoritas, hubungan yang terkait antara ekonomi dan politik dapat diartikan sebagai isu hubungan antara kekayaan dan kekuasaan. Penciptaan dan pendistribusian kekayaan terkait erat dalam permasalahan ekonomi, begitu juga dengan penciptaan dan pendistribusian kekuasaan yang terkait dengan politik. Perbedaan antara segi 
ilmu ekonomi dan ilmu politik sebagai ilmu kekayaan dan kekuasaan sekedar memiliki tujuan analitis. Pada kenyataannya kekayaan dan kekuasaan tidak bisa dipisahkan satu sama lain (Mohtar Mas'oed dalam Deliarnov, 2006:7).

\section{Ekonomi Politik dalam Lintasan Sejarah Ekonomi Politik Pra Klasik}

Ekonomi Politik sudah menjadi bahasan pada masa Yunani Kuno yang semakin berkembang pada Abad ke-14. Pada abad terjadi Revolusi Prancis, era kaum saudagar atau merchant berkuasa dikarenakan kemungkinan transisi kekuasaan dari raja dan gereja. Sehingga era ini disebut merkantilisme (Deliarnov, 2006:22).

Aliran pertama yang ada campur tangan negara dalam perekonomian ialah merkantilis. Banyak cara campur tangan negara dalam perekonomian, seperti memberi fasilitas industri baru, monopoli dagang, dan pengenaan pajak impor. Hal yang sedemikian ini bertujuan untuk memperbesar surplus, agar negara semakin jaya. Di sisi lain, campur tangan negara hanya bisa dinikmati oleh kalangan pengusaha yang berkolaborasi dengan jajaran penguasa (Deliarnov, 2006:23).

Kaum fisiokrat menganggap kelas produksi yang terdiri dari petani, peladang dan yang bergerak dalam usaha tambang merupakan pahlawan kemakmuran. Dalam era merkantilisme, petani harus membayar pajak tinggi dan pungutan liar. Kaum petani yang tidak terima akan melawan kelompok saudagar. Hal semacam ini, Francous Quesnay sebagai bahaya laten dan sampai lah puncaknya pada akhir abad ke-18. Kaum fisiokrat meminta aktivitas ekonomi tidak perlu diatur oleh pemerintah, dengan meminta monopoli serta kemudahan sekelompok orang dihapuskan dan tidak ada lagi sekat dalam perdagangan. Pandangan ini yang menjadi cikal bakal dari perdagangan bebas yang digagas oleh Adam Smith dengan mendasarkan pada prinsip laissez faire laissez passer (Deliarnov, 2006:23).

\section{Ekonomi Politik Klasik}

Menurut Adam Smith, salah satu inti pemikiran ekonomi politik liberal klasik ialah kebebasan harus diberikan pada pelaku-pelaku ekonomi untuk mengejar kepentingan pribadi dan yang terbaik bagi dirinya (individual freedom of action). Kebebasan diberikan kepada konsumen untuk melakukan aktivitas konsumsi yang memberikan kepuasan sebesar-besarnya (utility maximization) baik berupa barang maupun jasa sesuai dengan selera dan kemampuan. Demikian halnya kebebasan yang diberikan kepada produsen untuk melakukan aktivitas produksi yang memberikan keuntungan sebersarbesarnya (profit maximization) dengan input dan teknologi untuk menghasilkan barang ataupun jasa. Dalam persaingan sempurna, mekanisme pasar tanpa campur tangan pemerintah akan menciptakan keseimbangan. Dalam 
pasar persaingan sempurna, ada invisible hand yang membuat pasar ini bersifat self-regulating dan self-correcting yang dapat mengarahkan ke keseimbangan pemanfaatan sumber daya penuh (Deliarnov, 2006:30).

\section{Ekonomi Politik Sosialis}

Masyarakat sosialis yang ditonjolkan ialah kebersamaan, dan komunisme menjadi salah bentuk masyarakat sosialis yang paling ekstrim, segala keputusan ekonomi disusun, direncanakan, dan dikontrol oleh negara. Jika dilihat dari sistem ekonomi politik, sosialisme ialah sebuah sistem yang berlandaskan pada kebersamaan, kepemilikan alat produksi dan distribus memiliki sifat kolektif (Deliarnov, 2006:39).

\section{Ekonomi Politik Neo-Klasik}

Menurut Grindle dalam Deliarnov (2006:64), teori ekonomi politik neoklasik dapat dibedakan menjadi dua, yaitu :

1. Pendekatan terpusat ke masyarakat atau society centred approach yang lebih ditekankan pada penggunaan pasar politik oleh agen ekonomi (Deliarnov, 2006:64).

2. Pendekatan terpusat ke negara atau state centred approach yang lebih ditekankan pada penggunaan sumber daya ekonomi oleh pelaku politik untuk tujuan politik (Deliarnov, 2006:64).

\section{Ekonomi Politik Islam}

\section{Ekonomi Politik Masa Rasulullah SAW}

Dalam hal perekonomian, Rasulullah mengajarkan transaksi-transaksi secara jujur, adil dan tidak pernah membuat pelanggan merasa kecewa. Bertanggung jawab dalam setiap transaksi yang dilakukan. Rasulullah Shallallahu Alaihi Wasallam juga memberlakukan larangan untuk menjaga seseorang untuk dapat berbuat adil dan jujur (Ibadi, 2007:12)

Lahirnya kebijakan fiskal ditengarahi oleh banyak faktor, salah satu dari faktor tersebut ialah merupakan bagian dari instrumen publik. Sektor-sektor yang menjadi sasaran Fiskal dari Rasulullah adalah sektor ekonomi, keuangan dan pajak (Ibandi, 2007:13).

Kebijakan moneter adalah sebuah tindakan dari penguasa untuk memengaruhi jumlah vang beredar yang mempunyai pengaruh pada kegiatan ekonomi di masyarakat. Kebijakan moneter ditujukan untuk mencapai sasaran ekonomi makro, seperti pertumbuhan ekonomi yang tinggi, stabilitas harga, pemerataan pembangunan, dan keseimbangan neraca pembayaran (Ibandi, 2007:15).

Menurut Ibandi

(2007:18), Kelebihan dari dinar dan dirham memiliki nilai relatif stabil. Jika permintaan uang mengalami kenaikan, maka vang akan diimpor. Jika permintaan vang menurun, maka komoditas akan diimpor. Pada masa itu tidak akan terjadi inflasi meskipun peredaran vang berlebih di masyarakat dikarenakan vang itu diubahnya menjadi perhiasan.

Sistem ekonomi yang ditetapkan oleh Rasulullah bersumber pada al-Quran. 
Prinsip pokok kebijakan ekonomi islam yang ada di dalam al-Quran (Ibandi, 2007:14) adalah:

1. Kekuasaan tertinggi adalah milik Allah

2. Manusia bukan pemilik sebenernya, hanya sebagai Khalifah di bumi

3. Semua yang dimiliki dan didapat adalah rahmat Allah

4. Kekayaan tidak boleh ditimbun dan harus selalu berputar

5. Eksploitasi ekonomi dengan segala bentuknya harus dihilangkan, seperti Riba

6. Sistem warisan sebagai redistribusi kekayaan

7. Penetapan berbagai bentuk sedekah, wajib ataupun sukarela

\section{Ekonomi Politik Masa Khulfaur Rasyidin}

Setelah di bai'at Khalifah Abu

Bakar melakukan berbagai penataan internal dan eksternal. Dalam bidang ekonomi memilik prinsip mensejaterahkan umat Islam namun kebijakan-kebijakan itu masih sama pada masa Rasulullah. Menurut Amalia dalam Ibandi (2007:27), beberapa kebijakan umum yang dilakukan oleh Abu Bakar selama masa menjadi khalifah antara lain

1. menegakan hukum dengan memerangi mereka yang tidak mau membayar zakat.

2. tidak menjadikan ahli badar lorang yang ikut serta dalam peperangan badar) sebagai pejabat negara
3. tidak memberikan keistimewaan kepada ahli badar dalam pembagian kekayaan negara

4. dikelolanya barang tambang (rikaz) yang terdiri emas, perak, perunggu, besi dan baja sehingga menjadi sumber pendapatan negara

5. menetapkan prinsip kesamaan dalam pendistribusian kekayaan dan penetapan gaji pegawai berdasar dari karakteristik daerah serta kekuasaan

6. tak ada perubahan kebijakan Rasulullah pada masalah Jizyah

7. Perhatian terhadap akurasi perhitungan dalam Zakat.

Pendapatan negara mengalami peningkatan disebabkan oleh ekspansi wilayah yang dilakukan oleh Khalifah Umar bin Khattab. Untuk mengelola kas negara secara terencana dan terarah, Umar bin Khattab mengeluarkan kebijakan setelah bermusyawarah dengan Majelis Syura yang telah dibentuknya. Lembaga Baitul Maal memiliki peran penting dalam tata kelola kevangan negara. Maka didirikanlah baitul maal di beberapa wilayah dan kota madinah menjadi kantor pusatnya (Ibandi, 2007:31).

Kebijakan fenomenal pada masa Umar bin Khattab dalam bidang ekonomi adalah kebijakan kepimilikan tanah. Menurut Chamid dalam Ibandi (2007:32), kebijakan ini timbul karena penaklukan sehingga memunculkan masalah baru untuk mengelola tanah secara produktif. 
Bermula dari Ibn Abi Waqqa mengirim utusan ke kota Madinah untuk memberikan informasi kepada Khalifah Umar bin Khattab, bahwa umat islam telah memasuki al-Madain, ibukota Sasania, yang menyimpan harta kekayaan berlimpah sejak ratusan tahun silam. Mendengar hal tersebut Umar bin Khattab beristighfar kepada Allah. Sebab umat islam sibuk mengumpulan kekayaan dan lupa akan tujuan menyebarkan asma Allah serta hadits Nabi Muhammad Shalallahu Alaihi Wasallam (Karim dalam Ibandi, 2007:32).

Menurut Karim dalam Ibandi (2007:38), periode 12 tahun pemerintahan Khalifah Utsman bin Affan dibagi menjadi dua, periode kemajuan dan periode kemunduran sampai meninggalnya khalifah Utsman. sebagai Khalifah, Utsman bin Affan seorang yang jujur dan saleh, tetapi sangat tua serta lemah lembut. Awal pemerintahan hanya melanjutkan dan mengembang kebijakan yang sudah ada pada masa Khalifah Umar bin Khattab. Menurut Chamid dalam Ibandi (2007:38), Utsman bin Affan saat menemui kesulitan, mulai menyimpang dari kebijakan yang diterapkan pendahulunya. Periode enam tahun pertama, Utsman bin Affan membawa kemajuan luar biasa serta wilayah kekuasaan islam semakin meluas. Pemasukan negara yang diperoleh dari hasil zakat, jizyah dan kharaj menjadi semakin besar. Serta seluruh kekayaan Khalifah Utsman bin Affan di dermakan untuk Baitul Maal.
Namun periode enam tahun selanjutnya, pemerintahan Khalifah Utsman mengalami kemunduran serta fitnah terjadi dimana-mana. Ada beberapa sebab pemerintahan Khalifah Utsman bin Affan mengalami chaos. Lemahnya kontrol pemerintahan islam sejak Utsman bin Affan lanjut usia (Ibandi, 2007:40). Menurut Tahqia dalam Ibandi (2007:40), adanya pencemaran isu nepotisme di tubuh pemerintahan Khalifah Utsman bin Affan serta mencemarkan nama baik pegawai dan gubernurnya.

\section{Objek Materi Ekonomi Politik}

\section{Produksi}

Menurut Herawati (2008), produksi tidak terlepas dari penggunaan sumber yang ada untuk menciptakan suatu barang dengan nilai guna baru, sehingga barang ataupun jasa yang dihasilkan mempunya nilai ekonomis untuk mencapai tujuan perusahaan dengan menghasilkan laba dari aktifitas yang dilakukan.

\section{Mekanisme Pasar}

Pasar menjadi refleksi keinginan masyarat serta kebutuhan individu (Deliarnov, 2006:29). Menurut Sheldon dalam Deliarnov (2006:29), motor penggerak kesejahteraan ialah pasar. Nicholson dalam Deliarnov (2006:29) berpendapat pasar persaingan sempurna memberikan hasil yang optimum dan membawa perekonomian pada suatu keseimbangan yang sempurnal. Bahkan sistem pasar dapat mengurangi diskriminasi ras dan etnin, karena 
konsumen membeli bukan karena latar belakang ras, etnik atau agama dari penjual melainkan dari penawaran dengan harga renda dan kualitasnya (Fietman dalam Deliarnov, 2006:29).

\section{Teori Pembagian Kerja}

Para ekonom masa kini mengenal teori pembagian kerja melalui apa yang dibawa oleh Adam Smith. Menurut Adam Smith, pembagian kerja perlu dilakukan untuk mendapatkan hasil yang lebih baik. Adam Smith berpendapat jika setiap orang mengerjakan semua aktifitas dalam pembuatan peniti, maka hasil yang diperoleh tidak seberapa. Jika dibandingkan dengan setiap orang melakukan aktifitas tertentu dalam proses pembuatannya maka hasil yang diperoleh jauh lebih besar (Deliarnov, 2006:26).

\section{Teori Upah}

Beberapa teori tentang upah dari beberapa tokoh, seperti teori upah alami, teori upah besi, teori dana upah, dan teori upah ethis. Teori upah alami menurut David Ricardo ialah upah yang wajar, upah yang menjadikan biaya hidup minimum pekerja beserta keluarga menjadi dasar dan sesuai dengan kemampuan perusahaan. Sedangkan teori upah besi dari Ferdinand Lasalle, menekankan upah pekerja serendah mungkin untuk mendapatkan keuntungan maksimal. Hal ini membuat kaum pekerja membentuk serikat pekerja. Adapun teori dana upah dari Mill ialah upah tergantung dari persediaan dana perusahaan untuk pembayaran upah dan jumlah pekerja, jika jumlah pekerja meningkat makan upah akan turun. Teori upah ethis dari Von Thunen ialah besar upah tergantung pada besar pemeliharaan hidup dan produktifitas dari kerja buruh sehingga bisa menjamin kehidupan layak bagi pekerja beserta keluarga (Herdiansyah, $2011: 5$ ).

\section{METODE PENELITIAN}

\section{Pendekatan Penelitian}

Dalam penelitian ini, pendekatan yang digunakan ialah jenis pendekatan library research atau studi kepustakaan. Penelitian studi kepustakaan merupakan bagian dari penelitian kualititatif yang menekankan pada hal terpenting dari sifat suatu barang ataupun jasa. Hal terpenting dari suatu barang atau jasa berupa fenomena adalah makna dibalik kejadian tersebut yang dapat dijadikan pelajaran berharga bagi suatu pengembangan konsep teori (Satori dan Komariah, 2011:22).

Penulisan studi kepustakaan juga dipilih karena data penelitian yang akan dianalisis maupun dikumpulkan berupa kata-kata (lisan atau tulisan) dan perbuatan-perbuatan manusia, yang dalam penelitian ini adalah pemikiran ekonomi politik islam menurut Ibnu Khaldun yang peneliti tidak berusaha menghitung serta mengkuantifikasi dari data-data tersebut (Afrizal, 2014:3).

\section{Objek Penelitian}

Objek material yang dikaji dalam penelitian ini adalah mengenai pemikiran ekonomi politik islam menurut Ibnu Khaldun. Objek material dalam penelitian ini mengandung unsur ilmu ekonomi, ilmu 
sosial, ilmu sejarah serta terkait juga dengan agama islam sehingga termasuk dalam kajian interdisipliner.

Adapun objek formal dalam penelitian ini adalah ekonomi politik islam yang difokuskan pada teori-teori yang dikemukakan dalam pemikiran oleh Ibnu Khaldun.

\section{Jenis Data dan Prosedur Pengumpulan Data}

Pada penelitian ini jenis data yang digunakan ialah data kepustakaan yang ada keterkaitannya dengan objek formal dan objek material penelitian. Klasifikasiklasifikasi data kepustakaan yang digunakan dalam penelitian ini ialah sebagai berikut:

\section{Metode Pengolahan Data}

Langkah -langkah yang dilakukan dalam pengolahan data pada penelitian ini sebagaimana yang disebutkan oleh Kaelan (2012) adalah:

1. Reduksi Data, Data-data yang terkumpul berkaitan dengan pemikiran ibnu khaldun mengenai ekonomi politik islam dari berbagai literatur dirangkum dan diambil esensinya sebagai langkah awal analisis data.

2. Klasifikasi Data, Pada penelitian ini, data-data yang berkaitan dengan ekonomi politik islam dikelompokkan

3. Penyajian Data, Data-data yang berkaitan pemikiran Ibnu Khaldun mengenai ekonomi politik islam yang telah diklasifikasikan akan disajikan dengan bentuk narasi deskriptif dan bila diperlukan akan digambarkan dalam berupa tampilan grafis seperti diagram maupun tabel guna menjadi alat bantu untuk menjelaskan pemikiran Ibnu Khaldun mengenai ekonomi politik islam.

\section{Metode Interpretasi Data}

Langkah-langkah interpretasi data dengan metode dalam penelitian ini ialah sebagai berikut:

1. Rekonstruksi Biografis, Pada penelitian ini rekonstruksi biografi dilakukan kepada tokoh muslim yang dikenal dengan nama Ibnu Khaldun.

2. Verifikasi Historis, Pada penelitian ini, verifikasi historis menguji keabsahan karya dari tokoh muslim Ibnu Khaldun yang berjudul Muqaddimah, yang juga menjadi salah satu sumber utama dalam penelitian ini.

3. Deskriptif Historis, Pada penelitian ini. Tahapan deskriptif historis dilakukan dengan mengkaji peristiwa-peristiwa yang dialami oleh pemikir ekonomi politik islam Ibnu Khaldun.

4. Periodisasi, Pada penelitian ini, tahapan periodisasi dilakukan dengan mengkaji tahapantahapan pemikiran ekonomi politik islam dari lbnu Khaldun.

\section{HASIL DAN PEMBAHASAN}

\section{Biografi lbnu Khaldun}

Nama asli Ibnu Khaldun adalah Abdurrahman Ibnu Khaldun Al-Maghribi 
Al-Hadrami Al-Maliki. Diberi golongan kepada Al-Maghribi, karena Ibnu Khaldun lahir dan dibesarkan di suatu tempat yang bernama Maghrib di kota Tunis, diberi julukan Al-Hadrami karena keturunannya berasal dari Hadramaut Yaman, dan disebut Al-Maliki karena Ibnu Khaldun menganut madzhab Imam Malik. Gelar Abu Zaid diperoleh dari anak sulung Ibnu Khaldun yang memiliki nama Zaid. Gelar Wali Ad-Din juga disandangkan setelah Ibnu Khaldun menjadi Hakim di Mesir (Khaldun, 2001:1080).

Ibnu Khaldun dilahirkan di Tunisia pada awal bulan Ramadhan tepatnya pada tanggal 1 Ramadhan $732 \mathrm{H}$ (Enan, 1941:2). Ayahnya menjadi gurunya yang pertama. Pada masa itu Tunisia merupakan pusat berkumpulnya para ulama, dan para sastrawan di negaranegara Maghrib, serta menjadi pusat tempat hijrah para ulama-ulama Andalusia yang menjadi korban akibat situasi negeri yang tidak tenang (Wafi, 1985:11).

Guru-guru Ibnu Khaldun, diantaranya ialah Abu Abdullah Muhammad Ibnu Sa'ad bin Burral AlAnsari, darinya Ibnu Khaldun belajar AlQuran dan Al-Qiraat Al-Hasayiri. Ibnu Khaldun belajar bahasa Arab dari Muhammad Al-Syawwasy Al-Zarzali dan Ahmad ibnu Al-Qassar. IImu-ilmu hadits, bahasa Arab, serta fikih dipelajari Ibnu Khaldun dari Syaikh Syamsuddin Abu Abdullah Muhammad Al-Wadiyasyi. Kitab Al-Muwatta' karya Imam Malik didapati oleh Ibnu Khaldun dari Abdullah
Muhammad Ibnu Abdussalam. Serta guruguru yang membentuk kepribadian Ibnu Khaldun ialah Muhammad Ibnu Sulaiman Al-Satti Abd Al-Muhaimin Al-Hadrami dan Muhammad Ibnu Ibrahim Al-Abili. Dari guru tersebut juga Ibnu Khaldun belajar ilmu-ilmu pasti, logika dan seluruh ilmu (teknik), kebijakan dan pengajaran dua ilmu pokok yaitu Al-Quran dan Hadits ( Khaldun, 2001:1080).

Dalam usia empat puluh lima tahun, dengan pengalaman mengabdi kepada istana-istana dan negara-negara di Afrika Utara serta persoalan-persoalan atas lembaga-lembaga yang dipelajari. Perbukitan-perbukitan dan padangpadang yang telah dilintasi, bergaul dengan suku-suku Barbar, watak dan adat istiadat yang telah dipelajari. Pengunduran dirinya membawa rahmat bagi diri untuk menulis Muqaddimah ditempat yang jauh dan sunyi dan diselesaikannya pada pertengahan tahun 779 H (Audah, tth:28). Hingga masanya Ibnu Khaldun wafat pada 25 Ramadhan 808 H di Kairo, Mesir (Khaldun, 2003:1086).

\section{Karya Besar Ibnu Khaldun}

Menurut Nurcholis Madjid dalam Suharto (2003), Ibnu Khaldun yang hidup pada masa peradaban islam mulai mengalami kehancuran atau saat umat islam mengalami anti-klimaks pada peradabannya, namun mampu menjadi sebagai pemikir di kalangan muslim yang kreatif dan melahirkan pemikiran besar melalui buah karya, hampir seluruh pemikiran itu bersifat orisinil dan kepeloporan. Diantaranya: 
1. Muqaddimah

2. Al Ibar

3. At-Ta'rif bi Ibnu Khaldun

Teori Produksi dalam Pemikiran Ibnu Khaldun

Ibnu Khaldun membedakan produksi pada aktifitas manusia secara sosial dan internasional. Pada tabiatnya manusia ialah makhluk ekonomi, yang pada akhirnya manusia akan memiliki tujuan untuk produksi. Keutamaan dalam faktor produksi ialah tenaga kerja manusia.

Oleh sebabnya maka dalam mencukupi kebutuhan sehari-sehari manusia diharuskan melakukan produksi, begitu juga sebaliknya produksi juga tidak akan ada tanpa adanya tenaga manusia. Aktifitas produksi menjadi aktifitas yang penting bagi manusia. untuk mencari nafkah dan bertahan hidup, manusia harus memenuhi tenaganya dengan makan. Manusia harus memproduksi makanannya sendiri. Dengan tenaganya lah manusia dapat memenuhi kebutuhan pangannya.

Melalui spesialisasi kerja, hasil produksi menjadi lebih besar. Secara agregat produksi yang dihasilkan oleh manusia yang bekerja secara bersamasama dan terorganisir lebih besar dibandingkan dengan jumlah total produksi individu dari setiap orang yang bekerja secara sendiri-sendiri, dan lebih besar dari jumlah yang dibutuhkan untuk bertahan hidup. Surplus yang tersisa ini juga dapat digunakan untuk berdagang.
Ibnu Khaldun memberikan anjuran untuk organisasi social dari aktifitas produksi melakukan spesialisasi tenaga kerja. Dengan spesialisasi inilah dapat memberikan hasil yang maksimal. Pembagian kerja inilah yang dapat menciptakan perdagangan antara produsen karena adanya surplus dari aktifitas produksi tersebut.

Adapun pembagian kerja yang lain ialah pembagian kerja secara internasional. Pembagian kerja internasional tidak didasarkan kepada kekayaan sumber daya alam dari masingmasing Negara namun didasarkan kepada keterampilan yang dimiliki oleh penduduk Negara tersebut

Ibnu Khaldun memandang bahwa yang memiliki keterampilan dipandang lebih baik, karena dalam melaksanakan pekerjaannya itu tidak membawa dampak yang merugikan. Jika ada yang merugikan melalu sifat dengan tidak adanya kejujuran, Ibnu Khaldun memberikan saran dengan mengadakan pengawasan yang lebih. (Rus'an. 1963:119)

Teori Nilai, Uang dan Harga dalam Pemikiran Ibnu Khaldun

Menurut Ibnu Khaldun, nilai dari suatu produk tergantung dari jumlah tenaga kerja yang menghasilkannya. Boulakia (1971:1109-1110), kekayaan dari suatu Negara tidak didasarkan pada jumlah uang yang Negara itu miliki, melainkan didasarkan pada produksi dari barang atau jasa dan sehatnya keuangan Negara tersebut. Dua hal ini 
terkait satu sama lain. Tingginya tingkat produksi selaras dengan kesehatan keuangan Negara.

Ibnu Khaldun mendukung standar moneter dengan menggunakan emas dan perak. Ibnu Khaldun berkeyakinan vang logam merupakan jaminan yang diberikan oleh penguasa bahwa sekeping vang logam memiliki kandungan kadar emas dan perak tertentu. Pada masa Ibnu Khaldun, kantor percetakan merupakan kantor religious, sehingga tidak terikat dengan atura-aturan tertentu. Dan koinkoin yang sudah diterbitkan tidak dapat diubah kandungan emas dan peras di kepingan tersebut.

Bagi Ibnu Khaldun, harga berasal dari permintaan dan penawaran, pengecualiannya ialah logam emas dan perak yang menjadi standar moneter. Semua barang yang lain mengalami fluktuasi harga, tergantung dari permintaan dan penawaran yang ada di pasar. Jika penawaran barang itu rendah maka permintaan akan meningkat, begitu pula harga barang tersebut. Sebaliknya, jika penawaran barang itu berlimpah ruah, harga akan berbanding terbalik.

Teori Distribusi dalam Pemikiran Ibnu Khaldun

Boulakia (1971:1111) menyebutkan harga suatu produk juga dipengaruhi oleh gaji, laba, serta pajak. Gaji merupakan imbalan bagi yang memproduksi, laba merupakan imbalan bagi para pedagang, serta pajak merupakan imbalan bagi para pegawai negeri maupun penguasa. Jadi, Ibnu Khaldun membagi perekonomian menjadi tiga sector: produksi, perdagangan dan pelayanan masyarakat. Harga dari gaji, laba, serta pajak juga dipengaruhi oleh permintaan dan penawaran.

Pendapatan nasional menurut Ibnu Khaldun dibagi menjadi tiga kategori: gaji, laba dan pajak. Keuntungan maksimal yang didapat dari masingmasing sector tersebut tidak dapat berlangsung lama karena adanya siklus ekonomi.

\section{Siklus Populasi dalam Pemikiran Ibnu Khaldun}

Populasi menjadi faktor penting dalam produksi. Semakin banyaknya populasi, semakin banyak produksi yang akan dihasilkan. Sehingga pada nantinya, semakin besar populasi akan meningkatkan permintaan terhadap pasar dan semakin besar total produksi yang dihasilkan.

Namun populasi dengan produksi saling terikat satu sama lain, saling memiliki pengaruh satu sama lain. Besarnya produksi akan menyebabkan banyaknya permintaan terhadap tenaga kerja di pasar. Semakin tinggi gaji yang diperoleh tenaga kerja, semakin banyak tenaga kerja yang cenderung untuk bekerja di tempat tersebut, hal ini akan memicu naiknya populasi pada tempat tersebut. Sehingga, proses pertumbuhan populasi menentukan pertumbuhan ekonomi, begitu juga pertumbuhan ekonomi turut menumbuhkan pertumbuhan populasi.

Meningkatnya jumlah populasi membutuhkan tambahan produksi di 
sektor agrikultur sebagai penyedia kebutuhan pokok para tenaga kerja. Meningkatnya jumlah populasi pada suatu menyebabkan kota tersebut menambahkan produksi manufaktur sehingga menurunkan produksi agrikultur, jumlah para petani pun ikut menurun. Naiknya taraf hidup para tenaga kerja membuat harga barang-barang turut naik. Sehingga laba sektor manufaktur lebih tinggi dibandingkan dengan sektor agrikultur, keinginan para petani untuk produksi ikut menurun. Sehingga ketersediaan pangan tidak akan cukup untuk penduduk kota. Timbulnya kelaparan dan wabah penyakit ini dampak tidak tercukupnya ketersediaan pangan.

\section{Keuangan Publik dalam Pemikiran Ibnu Khaldun}

Pengeluaran keuangan publik bagi Ibnu Khaldun menjadi sangat penting. Populasi akan meningkat jika infrastruktur telah dibangun oleh Negara dengan baik. Hal ini tidak akan terjadi bila tanpa adanya pembangunan infrastruktur yang telah disiapkan oleh Negara dengan pengeluarannya. Tenaga kerja takut berproduksi jika dalam situasi kacau atau perang, tanpa adanya kestabilan politik.

Pajak menjadi sumber penerimaan negara. Uang-uang yang dibelanjakan berasal dari sumber ini, pajak. pengeluaran Negara bisa meningkat jika penerimaannya ditingkatnya, meningkatkan pajak tersebut. Namun pajak yang tinggi akan membuat para tenaga kerja tidak semangat untuk bekerja.

Jika Negara memungut pajak yang rendah, penduduk akan menikmati laba yang besar. Imbasnya akan membawa semangat penduduk dalam bekerja. Namun kebutuhan Negara akan terganggu, naiknya tekanan fiskal. Laba dari penduduk akan turun, serta kehilangan semangat untuk bekerja. Produksi turun. Sehingga Negara tidak dapat menurunkan pengeluaran serta pajak. tekanan fiskal naik. Negara akhirnya menjalankan usaha penduduk, karena penduduk tak lagi memiliki laba guna menjalankan usaha tersebut. Sehingga Negara menjadi pelaku usaha dominan di pasar, mematikan usahausaha penduduk yang tidak dapat bersaing. Laba menurun, pendapatan menurun, negara menjadi miskin. karena Negara yang tak lagi kaya, populasi menjadi menurun akibat tenaga kerja yang memilih tempat lebih baik. Peradaban Negara tersebut menjadi runtuh.

Aktiftas-aktifitas komersial yang dilakukan oleh penguasa dapat kembali merugikan Negara, yang diawali dengan ruginya penduduk dan terganggunya penerimaan pajak yang diterima.

ada keadaan memaksa negara untuk memunguat banyak pajak dan memaksa pemerintah untuk membelanjakan lebih banyak, untuk memicu produksi. Sehingga muncul siklus perekonomian dimana mengalami perkembangan maupun depresi. 
Teori Pembangunan dalam Pemikiran Ibnu Khaldun

"The World is a garden the fence of which is the dynasty. The dynasty is an authority through which life is given to proper behaviour. Proper behaviour is a policy directed by the ruler. The ruler is an institution supported by the soldiers. The soldiers are helpers who are maintained by money. Money is sustenance brought together by subjects. The subjects are servants who are protected by justice. Justice is something familiar, and through it, the world persists. The world is a garden . . ' and then it begin again from the beginning" (Khaldun, 1978:41)

Ungkapan Ibnu Khaldun ini yang ada dalam Muqaddimah lalu yang menjadi sandaran Umar Chapra dalam mengillustrasikan lingkaran dinamis yang saling mempengaruhi kemajuan dan kemunduran serta runtuhnya suatu peradaban.

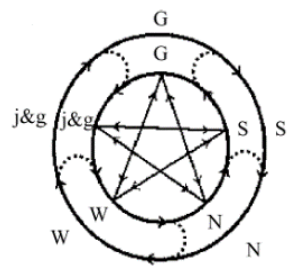

Pemerintah (G) tidak dapat memperoleh kekuasaan tanpa adanya manusia (N). Manusia tidak dapat bertahan tanpa adanya kekayaan (W). Kekayaan tidak dapat tercipta tanpa adanya pembangunan (g). Pembangunan dapat dicapai jika tercapainya Keadilan (j). Keadilan tidak dapat diwujudkan tanpa adanya syariah
(S). Syariah hanya bisa ditegakkan oleh Pemerintah.

\section{Konsep Kota (Madina) dalam Pemikiran Ibnu Khaldun}

Ibnu Khaldun memiliki pandangan pengembangan kota ialah tahap selanjutnya dari tatanan hidup budaya lama, Umran Badawi. Melalui proses didirikan ataupun melalui proses penaklukan, kota muncul dalam perubahan budaya masyarakat yang didasari oleh kekuatan dan dominasi.

Kota merupakan tahapan pertama munculnya budaya suatu daerah. Karakteristik dan ukuran dari sebuah kota dipengaruhi oleh kekuatan tiap negara tersebut yang juga menentukan kemakmurannya. Kekuatan inilah yang nanti akan membentuk sebuah negara (Dawla) atau bahkan kepada tahap peradaban (Hadara).

Abu Hantash

mengklasifikasikan ada empat tahapan siklus kota yang dipandang oleh Ibnu Khaldun:

1. Pembentukan dan berkembangnya keinginan masyarakat badui untuk mendapatkan kenyamanan dan kemudahan.

2. Pengembangan dan perluasan kota.

3. Kota mencapai tahap kemakmuran, penduduk menjadi terbiasa hidup dalam kemewahan dan mencari kepuasan. 
4. Kehancuran kota tak terhindarkan akibat penduduk yang terbiasa dalam hidup kemewahan.

\section{SIMPULAN}

Pemikiran Ibnu Khaldun mengenai Ekonomi-Politik dapat disimpulkan menjadi:

1. Ibnu Khaldun tidak berpihak kepada kapitalis, tidak berpihak juga kepada sosialis. Hal ini didasarkan pada ungkapan Ibnu Khaldun mengenai pedagang dan kebijakan pemerintah. Pemerintah tidak serta merta mengintervensi, namun pedagang juga tidak serta merta diberikan kebebasan penuh. Yang membuat perbedaan, Ibnu Khaldun memasukkan aspek religiusitas, agama yang bersumber pada AlQuran dan As-sunnah.

2. Pemikiran Ekonomi Politik Ibnu Khaldun, tidak hanya sekadar membicarakan aspek keadilan saja. Namun juga ada aspek kesejahteraan di dalamnya. Dan aspek-aspek ini saling mempengaruhi satu sama lain. Dan tauhid menjadi aspek yang memperkokoh kedua tersebut.

3. Ibnu Khaldun tidak hanya berbicara mengenai sektor mikro, namun juga sektor makro. Hal ini terlihat Ibnu Khaldun tidak membicarakan aktifitas pedagang, namun juga di lain kesempatan berbicara mengenai kebijakan pemerintah.
4. Produksi dalam pemikiran Ibnu Khaldun merupakan sebuah langkah manusia untuk memenuhi kebutuhannya dan faktor utama dalam produksi sendiri ialah manusia.

5. Spesialisasi kerja menjadi bagian penting untuk pertumbuhan ekonomi serta pembangunan ekonomi. Melalui spesialisasi kerja, hasil produksi menjadi lebih besar. Secara agregat produksi yang dihasilkan oleh manusia yang bekerja secara bersama-sama dan terorganisir lebih besar dibandingkan dengan jumlah total produksi individu dari setiap orang yang bekerja secara sendiri-sendiri, dan lebih besar dari jumlah yang dibutuhkan untuk bertahan hidup.

6. Ibnu Khaldun memandang bahwa yang memiliki keterampilan dipandang lebih baik, karena dalam melaksanakan pekerjaannya itu tidak membawa dampak yang merugikan. Jika ada yang merugikan melalu sifat dengan tidak adanya kejujuran, Ibnu Khaldun memberikan saran dengan mengadakan pengawasan yang lebih.

7. Ibnu Khaldun mendukung standar moneter dengan menggunakan emas dan perak dikarenakan pada masanya konstannya harga emas dan perak.

8. Harga berasal dari permintaan dan penawaran, 
pengecualiannya ialah logam emas dan perak yang menjadi standar moneter. Semua barang yang lain mengalami fluktuasi harga, tergantung dari permintaan dan penawaran yang ada di pasar. Jika penawaran barang itu rendah maka permintaan akan meningkat, begitu pula harga barang tersebut. Sebaliknya, jika penawaran barang itu berlimpah ruah, harga akan berbanding terbalik.

9. Pajak dalam pemikiran Ibnu Khaldun menjadi penting dalam penerimaan negara, namun pada kesempatan lain tingginya pajak juga dapat menimbulkan kelesuhan para pedagang.

10.Bagi Ibnu Khaldun variabelvariabel ini saling memengaruhi satu sama lain. Pemerintah (G) tidak dapat memperoleh kekuasaan tanpa adanya manusia (N). Manusia tidak dapat bertahan tanpa adanya kekayaan (W). Kekayaan tidak dapat tercipta tanpa adanya pembangunan (g). Pembangunan dapat dicapai jika tercapainya Keadilan (j). Keadilan tidak dapat diwujudkan tanpa adanya syariah (S). Syariah hanya bisa ditegakkan oleh Pemerintah.

11.Suatu peradaban dapat bermula dari kota. Dan kota tidak selamanya jaya namun juga ada masanya. Kemewahan dapat membawa kehancuran, tidak hanya manusia itu sendiri namun juga peradaban.

\section{DAFTAR PUSTAKA}

Abu-Hantash, Tawfiq F. 1983. Ibn Khaldun and the City: A Study of The Physical Formation of Medieval Cairo.

Afrizal. 2014. Metode Penelitian Kualitatif Sebuah Upaya Mendukung Penggunaan Penelitian Kualitatif dalam Berbagai Disiplin Ilmu. Jakarta: Rajawali Press.

Al-Hamdi, Mohaned Talib. 2016. Ibn Khaldun: The Father of the Division of Labor.

Boulakia, Jean David C. 1971. Ibn Khaldun: A Fourteenth Century Economist.

The Journal of Political Economy.

Deliarnov. 2006. Ekonomi Politik.

Jakarta: Penerbit Erlangga.

Hamid, Edy Suandi. 2009. Akar Krisis Ekonomi Global dan Dampaknya Terhadap Indonesia. La Riba Jurnal Ekonomi Islam. Vol III.

Hardoon, Deborah. 2017. An Economy For The 99\%. Oxfam.

Heridansyah, Rizki. 2011. Pengaruh Pengalaman Kerja dan Tingkat Upah Terhadap Produktivitas Pekerja di UD. Farley's Kota Mojokerto. Unesa.

Ibandi, Ahmad. Dkk. 2017. Politik Ekonomi Islam Analisis Wacana Keislaman Abad VII-XIX M. Yogyakarta: LESFI.

Iqbal, Ichsan. 2012. Pemikiran Ekonomi Islam Tentang Uang, Harga dan Pasar. Jurnal Khatulistiwa - Journal of Islamic Studies, Volume 2. 
Fauzi, et al/Jurnal Ekonomi Syariah dan Terapan Vol. 6 No. 1 Januari 2019: 154-169; KONSEP EKONOMI POLITIK DALAM PERSPEKTIF ILMU KHALDUN

Khaldun, Ibn. tth. The Muqaddimah An Introduction to History. Terjemahan dari Bahasa Arab oleh Franz Rosenthal. $1967 . \quad$ London: Routledge \& Kegan Paul Ltd.
2001. Mukaddimah Ibnu Khaldun. Terjemahan oleh Masturi Irham, Malik Supar, dan Abidun Zuhri. 2011. Jakarta: Pustaka Al-Kautsar. 